\title{
Survey of Chilli Powdery Mildew in Latur and Nanded Districts against Leveillula taurica
}

\author{
Mahmad Haneef Peshaman ${ }^{1 *}$, M.S. Dadke ${ }^{1}$, B.P. Dandnaik ${ }^{1}$ and B. Zaheer Ahamed ${ }^{2}$ \\ ${ }^{1}$ Department of Plant Pathology, College of Agriculture Latur Vasantrao Naik \\ Marathwada Krishi Vidyapeeth, Parbhani-431 402 (M.S), India \\ ${ }^{2}$ SMS, KVK, Kalaburgi, UAS Raichur, Karnataka, India \\ *Corresponding author
}

\section{A B S T R A C T}

Keywords

Chilli, Disease,

Powdery mildew,

Survey.

Article Info

Accepted:

15 October 2017

Available Online:

10 December 2017
A Survey was conducted in 2014-15 in Latur and Nanded districts of Maharashtra for the presence of powdery mildew of chilli. The results reveal that the maximum mean disease incidence recorded in Latur district $(49.42 \%)$ with mean severity of $(40.23 \%)$ Minimum mean disease incidence recorded in Nanded district $(44.70 \%)$ per cent with mean severity of 37.95 per cent, respectively. The variation of disease severity at various locations is mainly attributed to the climatic factors like temperature, relative humidity, distribution of rainfall followed by varieties grown cultural practices like sanitation and other suitable management practices. The other factors like age of the crop, cool nights and dry weather situation were also favourable for the powdery mildew to become severe.

\section{Introduction}

Chilli (Capsicum annum L.), belongs to the family Solanaceae is an important spice cum vegetable crop of the world. It is believed to be originated from South America during $15^{\text {th }}$ Century (Pickersgill, 1997). Powdery mildew incited by Leviellula taurica Lev. (Arn) is one of the important fungal diseases in chilli (Capsicum annum) causing considerable losses. The disease reported to occur and cause yield losses to the tune of 50.55 per cent in the Marathwada region of the state (Hingole and Kurundkar, 2011). The Portuguese during $15^{\text {th }}$ century introduced chilli crop to India from Brazil. India is the world's largest producer, consumer and exporter of chilli and contributes about 25 percent of total world production. In India chilli is grown in almost all the states. Andhra Pradesh is the largest producer of chilli occupying 27 percent followed by Karnataka (19\%) and Maharashtra (12\%) (Chandra Nayaka et al., 2009). In India During 201011 , chilli is grown an area of 792.1 thousand ha, with a production of 1223.4 MT and productivity of $1.5 \mathrm{MT} / \mathrm{ha}$ (Bijay Kumar, 2011). Maharashtra state have approximately one lakh hectare area under chilli, out of which 68 per cent area is in Nanded, Jalgaon, 
Dhule, Nandurbar, Solapur, Kolhapur, Amravati, Chandrapur, and Osmanabad districts (Rawtekar, 2003). Chilli suffers from many diseases caused by fungi, bacteria, and viruses. Among the fungal diseases, powdery mildew, wilt, leaf spots and anthracnose are the most prevalent ones.

\section{Materials and Methods}

A Roving survey of chilli fields in the Latur and Nanded districts of Marathwada region was undertaken during September to December (2012) The observations on incidence and severity of chilli powdery mildew was recorded as per the disease rating scale given by Mayee and Datar (1986).

\section{Results and Discussion}

An extensive survey was carried out during 2012-13 in the month of November to February in Latur and Nanded districts in different farmers' fields. Survey was done in Latur, Ausa, Nilanga, Chakur, and Renapur tahsils of Latur districts and Biloli, Degloor, Umari, Dharmabad and Loha tahsils of Nanded districts of Marathwada region to find out incidence and severity of powdery mildew disease of chilli in farmers field. The observations on incidence, intensity are presented in table 2 and 3. Five tahsils in Latur district of Marathwada region were surveyed. The results (Table 2 and 3) reveled that maximum disease incidence was recorded in Nilanga $(51.79 \%)$, which was followed by Ausa (50.67\%), and Chakur (49.78\%) (Fig. $1)$.

Minimum disease incidence was recorded in Latur (46.97\%), followed by Renapur (47.90\%).Among the five tahsils maximum disease severity was recorded in Nilanga tahsil (42.84\%), followed by Latur (41.85\%), and Ausa (40.57\%). Minimum disease severity was recorded in Renapur (37.06\%), followed by Chakur (38.86\%). Five tahsils in Nanded district of Marathwada region were surveyed. The result reveled that maximum disease incidence was recorded in Loha (49.44\%), followed by Nanded (47.77\%), and Umari (45.85\%). Minimum disease incidence was recorded in Dharmabad (36.94\%), followed by Degloor (43.72\%).Among the five tahsils maximum disease severity was recorded in Loha (42.21\%), followed by Nanded (40.29\%) and Umari (38.91\%). Minimum disease incidence was recorded in Dharmabad (31.20\%) followed by Degloor $(37.15 \%)$. This survey results revealed that maximum disease incidence recorded in Latur district (49.42\%), with mean severity (40.23\%). Minimum mean disease incidence (44.70\%) was recorded in Nanded district with mean severity of $37.95 \%$, respectively.

Table.1 Disease rating scale for powdery mildew of chilli

\begin{tabular}{|l|l|}
\hline Score & Description \\
\hline 0 & No symptom of powdery mildew \\
\hline 1 & Small scattered powdery mildew specks covering 1\% or less leaf area \\
\hline 3 & Small powdery lesions covering 1-10\% of leaf area \\
\hline 5 & Powdery lesions enlarged covering 11-25\% of leaf area \\
\hline 7 & $\begin{array}{l}\text { Powdery lesions coalesce to form big patches covering 26-50\% of } \\
\text { leaf area }\end{array}$ \\
\hline 9 & $\begin{array}{l}\text { Big powdery patches covering } 51 \% \text { or more of leaf area and } \\
\text { defoliation occur }\end{array}$ \\
\hline
\end{tabular}


Table.2 Powdery mildew incidence and severity in Latur district during Rabi 2012-13

\begin{tabular}{|c|c|c|c|}
\hline District/ Tahsil & Village & Incidence (\%) & Severity (\%) \\
\hline \multirow{5}{*}{ Latur } & Latur & 54.98 & 47.33 \\
\hline & Gangapur & 48.18 & 42.13 \\
\hline & Vasantgaon & 46.61 & 43.33 \\
\hline & Murud & 44.16 & 41.89 \\
\hline & Bhabalgaon & 40.94 & 34.60 \\
\hline Mean (\%) & & 46.97 & 41.85 \\
\hline \multirow{5}{*}{ Ausa } & Ausa & 42.13 & 41.56 \\
\hline & Budhoda & 52.21 & 39.17 \\
\hline & Lamjana & 54.38 & 40.45 \\
\hline & Killari & 50.19 & 41.89 \\
\hline & Peth & 54.45 & 39.75 \\
\hline Mean (\%) & & 50.67 & 40.57 \\
\hline \multirow{5}{*}{ Nilanga } & Nilanga & 53.78 & 43.59 \\
\hline & Hasegaonwadi & 52.34 & 45.13 \\
\hline & Nitur & 56.73 & 41.63 \\
\hline & Masalga & 47.75 & 43.89 \\
\hline & Panchincholi & 48.35 & 39.98 \\
\hline Mean (\%) & & 51.79 & 42.84 \\
\hline \multirow{5}{*}{ Chakur } & Chakur & 48.66 & 41.33 \\
\hline & Gharni & 51.20 & 39.63 \\
\hline & Nalegaon & 47.10 & 35.19 \\
\hline & Limbalwadi & 49.66 & 38.68 \\
\hline & Wadwal & 50.78 & 42.50 \\
\hline Mean (\%) & & 49.78 & 38.86 \\
\hline \multirow{5}{*}{ Renapur } & Renapur & 49.30 & 36.20 \\
\hline & Sukum & 47.66 & 38.91 \\
\hline & Kamkheda & 46.33 & 36.50 \\
\hline & Bhatamwadi & 49.13 & 35.73 \\
\hline & Pangaon & 47.11 & 37.98 \\
\hline Mean (\%) & & 47.90 & 37.06 \\
\hline Mean (\%) dist. & & 49.42 & 40.23 \\
\hline
\end{tabular}


Table.3 Powdery mildew incidence and severity in Nanded district during Rabi- 2012-13

\begin{tabular}{|c|c|c|c|}
\hline District/ Tahsil & Village & Incidence $(\%)$ & Severity (\%) \\
\hline \multirow{5}{*}{ Nanded } & Biloli & 52.46 & 43.46 \\
\hline & Badur & 47.37 & 39.37 \\
\hline & Kasrali & 44.84 & 37.44 \\
\hline & Bamni & 48.88 & 42.88 \\
\hline & Higni & 45.33 & 38.33 \\
\hline Mean (\%) & & 47.77 & 40.29 \\
\hline \multirow{5}{*}{ Degloor } & Degloor & 40.43 & 34.45 \\
\hline & Mukrambad & 46.35 & 39.20 \\
\hline & Khanapur & 41.10 & 35.18 \\
\hline & Kortatkhed & 44.48 & 36.98 \\
\hline & Sudgi & 46.24 & 39.98 \\
\hline Mean (\%) & & 43.72 & 37.15 \\
\hline \multirow{5}{*}{ Umari } & Umari & 45.33 & 37.85 \\
\hline & Nagathana & 49.93 & 42.33 \\
\hline & Somathana & 48.69 & 41.69 \\
\hline & Telgaon & 43.88 & 36.73 \\
\hline & Goratha & 41.45 & 35.95 \\
\hline Mean $(\%)$ & & 45.85 & 38.91 \\
\hline \multirow[t]{5}{*}{ Dharmabad } & Dharmabad & 37.35 & 33.31 \\
\hline & Rajpur & 33.43 & 27.83 \\
\hline & Magnalli & 35.75 & 29.34 \\
\hline & Belgujar & 38.87 & 31.75 \\
\hline & Yeovati & 39.33 & 33.78 \\
\hline Mean (\%) & & 36.94 & 31.20 \\
\hline \multirow[t]{5}{*}{ Loha } & Loha & 48.35 & 41.25 \\
\hline & \begin{tabular}{|l} 
Dhanura \\
\end{tabular} & 44.35 & 38.98 \\
\hline & Koregaon & 53.45 & 46.45 \\
\hline & Deulgaon & 51.15 & 43.85 \\
\hline & Sokhed & 49.93 & 40.56 \\
\hline Mean\% & & 49.44 & 42.21 \\
\hline Mean\% dist & & 44.74 & 37.95 \\
\hline
\end{tabular}


Fig.1 Powdery mildew incidence and severity in Latur and Nanded district during Rabi 2012-13

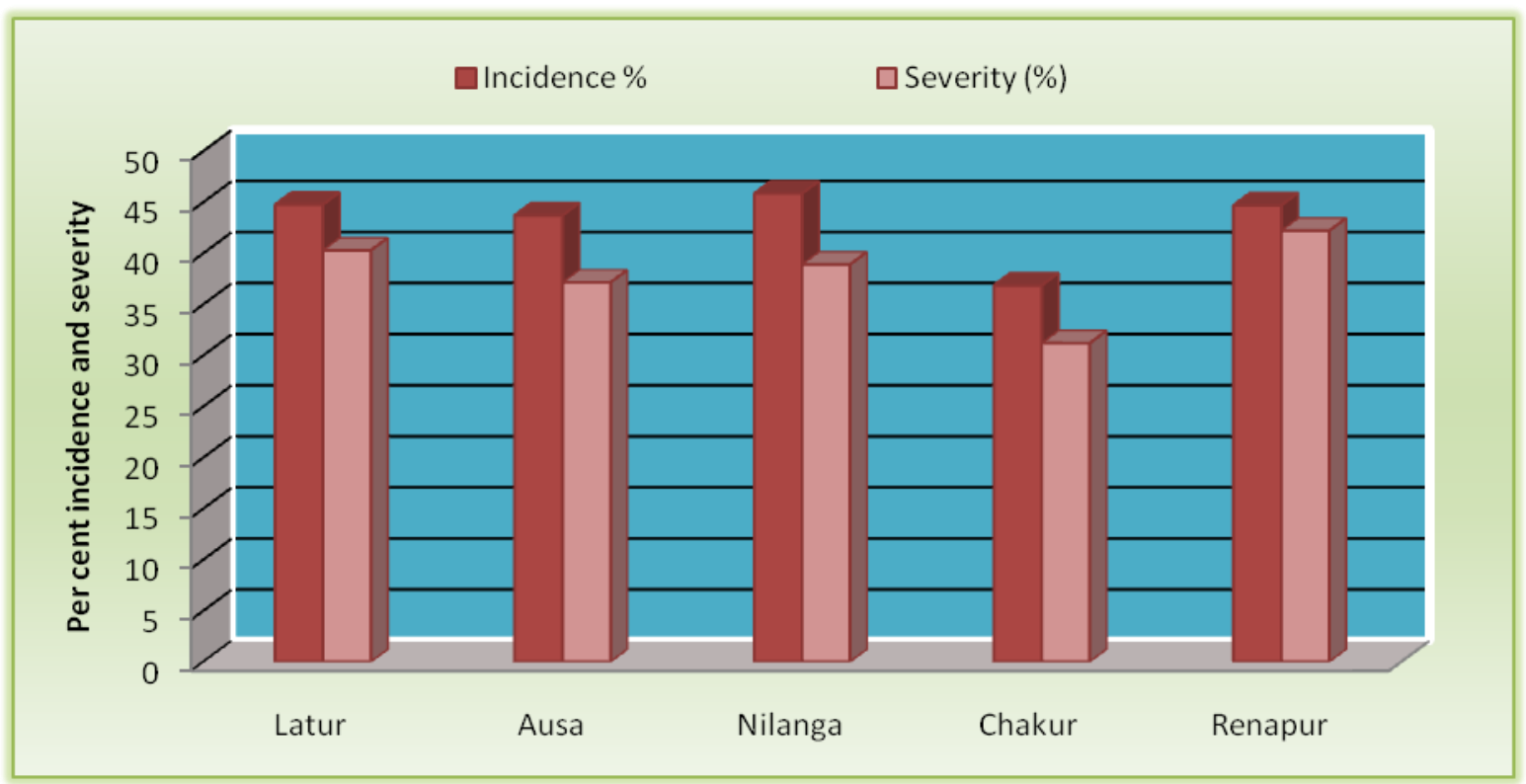

(i) Latur district

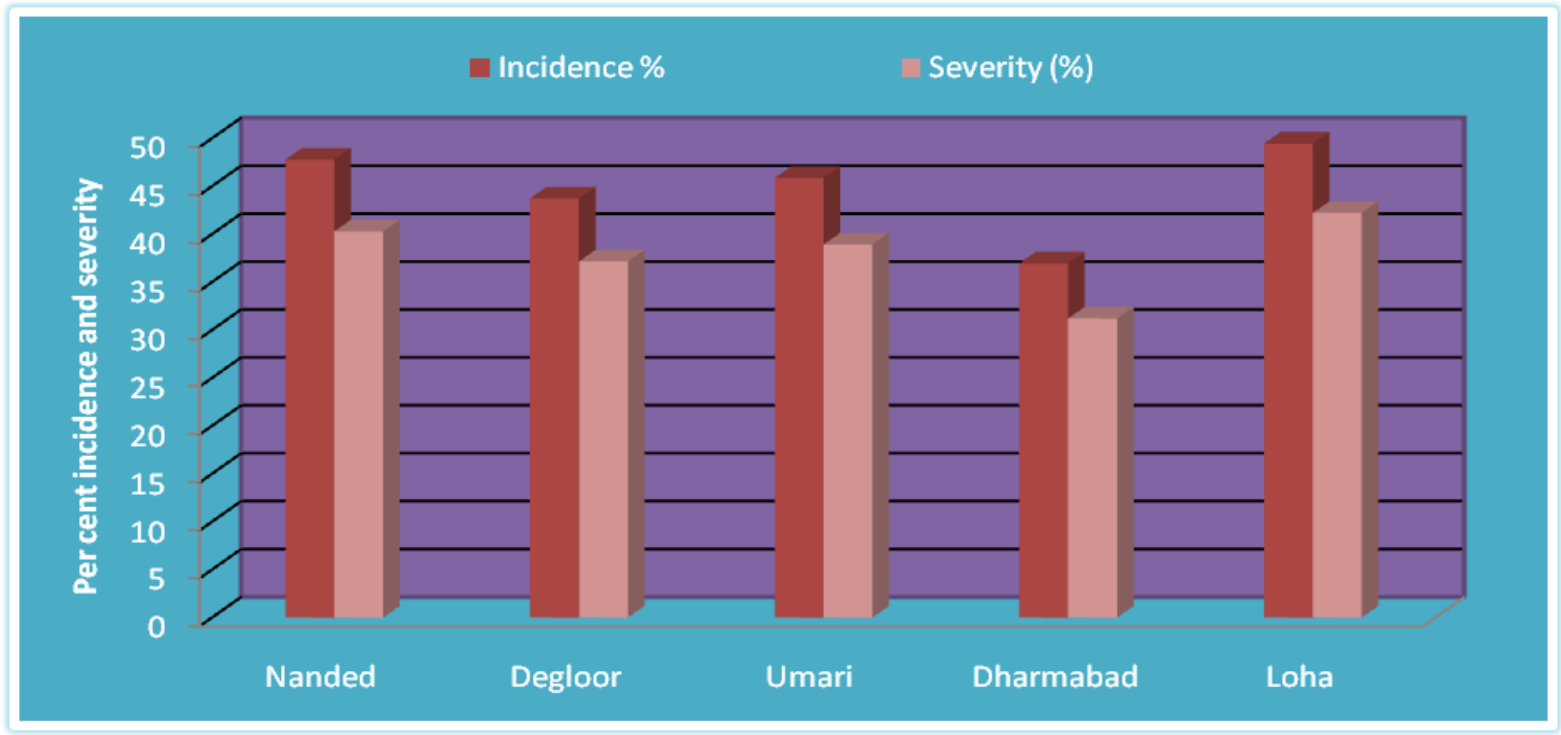

(ii) Nanded district

The variation of disease severity at various locations is mainly attributed to the climatic factors like temperature, relative humidity, distribution of rainfall followed by varieties grown cultural practices like sanitation and other suitable management practices. The other factors like age of the crop, cool nights and dry weather situation were also favourable for the powdery mildew to become severe (Aust and Jurgemen, 1986). The most frequent irrigation increases the disease severity when the susceptible age of the crop coincides with favourable weather parameters (Band et al., 2008). The reasons for the outbreak of powdery mildew disease in Latur $(49.42 \%$ incidence and severity $40.23 \%)$ Nanded districts $(44.74 \%$ incidence and severity $37.95 \%$ ) could be due to round the 
year cultivation of chilli crop. This not only exhausts the nutrients from the soil but paves the way for continuous survivability of the pathogen. The infected debris left in the field, serve as major source of infection causing epidemic throughout the season. Continuous cultivation of any crop over the seasons and years helps for buildup of inoculums level to such an extent that the epidemic is a common phenomenon (Chaube and Singh, 2001). Similar results were reported earlier by several research workers like Ashtaputre et al., (2007a), Dinesh et al., (2010), Sanjeev Kumar et al., (2010) and Akileshwari et al., (2012).The powdery mildew disease was less depended on factors such as location, cultural practices, followed by susceptibility of the cultivar grown, microclimate congenial for disease and meteorological factors such as temperature, relative humidity and rainfall (Ramesh et al., 2012).

Survey of powdery mildew incidence and severity in chilli growing areas of Latur and Nanded districts reveled that maximum disease incidence was recorded in Latur district $(49.42 \%)$ with mean severity of $40.23 \%$. Minimum mean disease incidence was recorded in Nanded district $(44.70 \%)$ with mean severity of 37.95 per cent, respectively.

\section{References}

Akhileshwari, S.V. Amaresh, Y. S. Naik, M. K. Kantharaju, V. and Shankergouda (2012). Survey and surveillance of sunflower powdery mildew in north eastern Karnataka. J. Pl. Dis. Sci. 7: 117-119.

Ashtaputre, S. A. Kulkarni, Srikant. Rao, M.S.L. and Shivaprasad, M. (2007a). Survey and surveillance for the incidence of powdery mildew of chilli in North Karnataka. Ann. Biol. 23 (2): 177-183.

Chaube, H.S. and R.S. Singh, (2001): Introductory Plant Pathology. International Book Distributing Co. Lucknow, pp. 132.

Dinesh, B. M. Shripad Kulkarni, Harlapur, S.I. Benagi, V.I. and Mallapur, C.P. (2010). Prevalence of powdery mildew in growing areas in sunflower, Northern Karnataka J. Agric. Sci. 23(3): 521-523.

Hingole, D.G. and Kurundkar B.P. (2011). Estimation of yield losses caused by anthrachnose and powdery mildew in chilli in Marathwada region. J. Pl. Dis. Sci. 6(2): 167-169.

Mayee, C.D. and Datar, V.V. (1986). Phytopathometry. Technical Bulletin 1 (special bulltien 3), Marathwada Krishi Vidyapeeth, Parbhani.

Pickersgill, B. (1997). Genetic resources and breeding of Capsicum spp. Euphytica. 96(1): 129-133.

Rawtekar, D. M. (2003). Mirchi lagwad (Chilli Cultivation). Phal Bag Vritta. (Marathi). pp. 13-14.

Sanjeev,K. RakeshShah, and Mali, B.L. (2010). Epidemiology and management of powdery mildew of red rose caused by Sphaerotheca pannosa var rosae. $J$. Pl. Dis. Sci. 5(1): 68-72.

\section{How to cite this article:}

Mahmad Haneef Peshaman, M.S. Dadke, B.P. Dandnaik and Zaheer Ahamed, B. 2017. Survey of Chilli Powdery Mildew in Latur and Nanded Districts against Leveillula taurica. Int.J.Curr.Microbiol.App.Sci. 6(12): 1859-1864. doi: https://doi.org/10.20546/ijcmas.2017.612.212 